\title{
'One of the few books that doesn't stink': The Intellectuals, the Masses and Gentlemen Prefer Blondes
}

\author{
FAYE HAMILL
}

\begin{abstract}
One of my most cherished mementoes of him is a delicate bottle of Schiaparelli perfume in a fancy pink box made in the shape of a book. On the fly-leaf Aldous wrote, 'For Anita, one of the few books that doesn't stink.' - Anita Loos, memoir of Aldous Huxley ${ }^{1}$
\end{abstract}

Anita Loos's tribute to Aldous Huxley appeared in a memorial volume compiled by Julian Huxley in 1966. Among the contributors were Lord David Cecil, Stephen Spender, T.S. Eliot, Osbert Sitwell, Leonard Woolf and Isaiah Berlin. Loos was one of Aldous Huxley's most famous friends: she was a successful and well connected screenwriter, and the astonishing sales of her novel Gentlemen Prefer Blondes (1925) made her a millionaire and a celebrity. The novel also significantly increased her cultural capital, since it was admired by eminent writers and thinkers including James Joyce, Edith Wharton, H.L. Mencken, William Faulkner, Sherwood Anderson, William Empson, George Santayana and Rose Macaulay. For many years, Loos was one of the best known women in the United States, and 1966 was the year she published her autobiographical volume $A$ Girl Like I, which received enthusiastic reviews and led to retrospectives of her films. ${ }^{2}$ And yet, if Anita Loos today stands out from the list of Julian Huxley's contributors, it is because the other names are still so familiar, while hers has become obscure.

Everyone recognizes the title Gentlemen Prefer Blondes, but very few people can give the name of the author. This testifies to the extent to which the 1953 musical film version has eclipsed the novel, detaching it both from its author and from its period. The director, Howard Hawks (in collaboration with Loos herself, as scriptwriter) abandoned the historical location of the original text, and transformed its girlish flapper heroines into what Susan Hegeman describes as 
'the larger-than-life feminine ideal of the postwar period: big, buxom, glittery'. Hegeman notes that while the film 'has been an important site for feminist scholarship', Loos's original book has not: 'critics who have addressed its popularity have done so with barely disguised embarrassment'. ${ }^{3}$ Film and popular culture are now, of course, legitimate objects of academic study; yet in the field of literary studies, the commercial success of a book still tends to preclude it from serious critical consideration, even in the case of so sophisticated a text as Gentlemen Prefer Blondes. In recent decades, feminist scholarship has reinstated many American authors who were eliminated from the canon under the influence of the post-World War I hostility to women's writing: ${ }^{4}$ among them, Willa Cather, Edith Wharton, Nella Larsen, Zora Neale Hurston, H.D., Amy Lowell and Edna St Vincent Millay. The rehabilitation of Anita Loos has been slow in comparison, and she continues to occupy a marginal position in the canon. ${ }^{5}$

The literary status of Loos's novel has, in fact, been ambiguous from the moment of its publication: the extravagant praise it received from numerous intellectuals was balanced by a number of ambiguous or hostile responses, notably those of William Faulkner, H.L. Mencken, Q.D. Leavis and Wyndham Lewis. Their rejection or undervaluing of Blondes can be explained in terms of contemporary attitudes to a range of interrelated issues, namely: comic writing, sexual morality and censorship, female authorship, mass culture and the commercialization of literature. Intriguingly, all of these subjects are actually thematized in Loos's writing. Gentlemen Prefer Blondes and its sequel, But Gentlemen Marry Brunettes (1928), are wide-ranging satires of interwar American culture, including among their targets consumerism and conspicuous consumption, psychoanalysis, Hollywood, New York high society, flapper culture, the discourses of self-improvement and positive thinking, Prohibition and censorship. The novels are narrated by the blonde Lorelei Lee, but much of the satire is conveyed through the cynical discourse of her brunette friend Dorothy Shaw, which is faithfully recorded (often with prudish disapproval) in Lorelei's diary. Lorelei's idiosyncratic, inaccurate and yet oddly charming prose is perhaps the novel's primary achievement. Barbara Everett argues that the 'peculiar force and flavour' of Gentlemen Prefer Blondes 'comes from the brilliant invention of its personal style'. ${ }^{6}$

Loos works the border between high and popular culture, never fully identifying herself with either. Her books are apparently aimed 
at a fairly educated audience, since their primary satiric target is a semiliterate, philistine lowbrow, but they also satirize the pretensions of highbrow culture. Loos's engagement with the interwar debate about 'brows' emerges in her ironic commentaries on the machinations of the male literary elite, the seductiveness of popular entertainments, and the 'puritanism' of American culture, a term that in the 1920s, as Malcolm Bradbury notes, 'becomes the great abuseword to assault the total lack of interest in, the total lack of effective environment for, the creative arts'. ${ }^{7}$ These are major themes of Gentlemen Prefer Blondes and its sequel, and similar preoccupations are evident in Loos's two other novels, No Mother To Guide Her (1930, revised 1960) and A Mouse Is Born (1951), as well as in her volumes of unreliable but revealing autobiography and memoir. This essay will therefore combine an account of the reception of Gentlemen Prefer Blondes with analysis of the strategies used within Loos's fictional and autobiographical texts to negotiate her relationship with the literary establishment and the popular culture of her period.

During the late 1920s and 1930s, Gentlemen Prefer Blondes elicited a surprising range of both admiring and censorious comments from writers and critics. Loos was particularly pleased by a 1926 fan letter from Aldous Huxley: 'I was enraptured by the book [and] have just hugely enjoyed the play'. ${ }^{8}$ James Joyce wrote to Harriet Shaw Weaver in the same year that he had been 'reclining on a sofa and reading Gentlemen Prefer Blondes for three whole days' $;{ }^{9}$ while Edith Wharton praised the book fulsomely in several letters. She demonstrates a strikingly broad concept of great literature, noting that that during an Aegean cruise, she and her friends read aloud to one another in the evening from 'The Odyssey or Blondes'.${ }^{10}$ Wharton also describes the book as a masterpiece in two unpublished letters, ${ }^{11}$ and she remarked to Frank Crowninshield, then editor of the prestigious New York journal Vanity Fair, 'I am just reading the Great American Novel (at last!) Gentlemen Prefer Blondes, and I want to know if there are - or will be - others, and if you know the funny woman, who must be a genius'. ${ }^{12}$ Her expectation of 'others' presciently anticipates the replication of Blondes in various forms (sequel, musical and film adaptations, spin-off products).

George Santayana named Blondes the best philosophical work by an American, ${ }^{13}$ and a similar half-amused, half-serious response is discernible in William Empson's 1937 poem, 'Reflection from Anita 
Loos'. He explains in a characteristically gnomic footnote that he was inspired by 'the fine character of Dorothy', and his poem represents men as constantly motivated by ambition and women as limited by their prescribed social roles: 'Gentlemen prefer bound feet and the wasp waist'. He glosses this theme in his note: 'The way earlier societies seem obviously absurd and cruel gives a kind of horror at the forces that must be at work in our own'. ${ }^{14}$ The layers of irony in Empson's notes caution the reader against unduly literal interpretations of his poems; nevertheless his comparison of the various methods of remaking the female body as male fantasy (footbinding, tightlacing and - by implication - hair dyeing) suggests that he has perceived a darker underside to Loos's novel. This presumably consists in its analysis of the relations between economics, sexuality and female freedom. The darkness of the poem itself is, however, relieved by its sing-song rhythm and humorous refrain: 'A girl can't go on laughing all the time'. This is rather typical of Empson: a number of his poems about tragedy and disaster have a disconcerting element of comedy in their manner. In this case, his deliberate mismatching of form and content may reflect his perception of the generic instability of Blondes itself. Susan Hegeman suggests that Empson considered Loos's novel as 'a tragedy problematically dressed up as satire', and she also notes that the comic/satiric mode of the book adversely affected its literary status. Comparing it to The Great Gatsby (1925), she comments that while both books are entirely of their time and 'address similar preoccupations with changes in the social conditions of ' $20 \mathrm{~s}$ America', critics in later decades judged The Great Gatsby 'to have transcended its moment ... redeemed by the cultural authority of tragedy', while Blondes was dismissed as a period piece. ${ }^{15}$

In fact, while Rose Macaulay's description of Gentlemen Prefer Blondes as 'probably the funniest book that has appeared in England or America' was used by the publishers to promote early editions, ${ }^{16}$ the devaluing of the novel on the grounds of its comic genre began as soon as the book was published. The influential critic and editor H.L. Mencken, Loos's close friend and the man whose admiration for a series of vacuous blonde women inspired the story, commented in his unsigned review in The American Mercury: 'This gay book has filled me with uproarious and salubrious mirth. It is farce - but farce full of shrewd observation and devastating irony. ${ }^{\prime 17}$ His statement evinces sincere admiration, but the terms 'gay', 'uproarious' and 'farce' 
consign the novel firmly to the non-serious, popular realm of literature. ${ }^{18}$ Loos also recalls that Mencken described the probable audience for Gentlemen Prefer Blondes as 'a frivolous public', ${ }^{19}$ a clearly gendered phrase.

Such judgements are informed by the age-old hierarchy of tragedy over comedy, which persistently manifests itself in an association of tragedy with the masculine, and comedy with both the feminine and the childlike. The language of Loos's reviewers and male friends frequently reduced her to the status of a girl or a child. Although Loos mocks Lorelei's calculatedly childlike behaviour (epitomized in her addressing her gentleman friends as 'Daddy'), she is at times complicit with the view of herself as a child, and also with the more general infantilization of women which was prevalent in her culture. She includes in the picture inserts in A Girl Like I a cartoon drawing of herself by Ralph Barton, which represents her as a diminutive figure sitting at a typewriter, her feet dangling in mid-air, with an enormous bow on the back of her dress and a vacant expression. The illustration originally appeared in a series of advertisements in Harper's Bazar, promoting the forthcoming sequel to Blondes, and, as Sarah Churchwell points out, these adverts 'promoted and simultaneously disavowed her resemblance to her characters' ${ }^{20}$ Loos seems happy to endorse Barton's representation, merely adding the caption: 'The only thing wrong with this picture is that an authoress like I never learned to type', deliberately distancing herself from mechanized methods of cultural production (the typewriter) and from association with low-grade forms of female work (the secretary) whilst retaining the image of herself as childlike. In her 1963 introduction to Gentlemen Prefer Blondes, 'The Biography of a Book', she recalls:

I began to write down my thoughts; not bitterly, as I might have done had I been a real novelist, but with an amusement which was, on the whole, rather childish. I have always considered grown-ups to be figures of fun, as children generally do, and have never been deceived by their hypocrisies. $^{21}$

She lists as 'real novelists' Anderson, Dreiser, Faulkner, Fitzgerald and Hemingway, making no mention of her female contemporaries. Despite her tongue-in-cheek tone, it is difficult not to suspect that Loos has internalized a conception of literature and high art as a male preserve. That this assumption was fundamental to the ideology of her 
period has been persuasively argued by recent theorists of modernism. Andreas Huyssen, for example, comments in his book After the Great Divide:

It is indeed striking to observe how the political, psychological, and aesthetic discourse around the turn of the century consistently and obsessively genders mass culture and the masses as feminine, while high culture, whether traditional or modern, clearly remains the privileged realm of male activities'. ${ }^{22}$

Loos's perception of the male novelists of her generation as 'real' writers and herself simply as a producer of popular culture (film scenarios, magazine fiction and bestselling novels) certainly reaffirms this gendered hierarchy of cultural forms.

In the area of fiction, the association of the popular and the feminine had some statistical basis. In the 1920s, the bestseller was indeed largely the preserve of women readers and writers, and this was also the period in which specialized genres of fiction and specialized magazines, all designed to appeal to women, began to proliferate. ${ }^{23}$ Of the ten bestsellers of 1925 in the U.S.A., eight were by women, though these eight covered a diverse range from Edna Ferber to Edith Wharton. ${ }^{24}$ However, Loos's attitude goes far beyond a simple acknowledgement of women's taste for, and success in, popular forms. Its most extreme expression comes in A Girl Like I: 'I had no pride in authorship because I never thought that anything produced by females was, or even should be, important. It is horrible to think what sort of monster Shakespeare might have been as a woman.' She adds: 'The only authoresses I ever respected were women first of all ... That they happened to take up writing was beside the point'. This emphatic reinscription of high culture as male conflicts, however, with her account of herself in the same text as a 'cérébrale' who is the intellectual peer of her male contemporaries and shares their knowledge of serious literature and their contempt for U.S. mass culture:

To me book learning didn't mean a thing unless it became an ingrained part of life. The majority of Americans don't realize what they're reading (unless it happens to be cheap pornography), hearing (except for rock and roll music), looking at (with the exception of television), or even tasting (unless it be hot dogs powerfully accentuated by mustard).... At any rate, a girl like I who never got past high school can take modest pride in making out quite well with the highbrows. I was once asked to preside 
over a symposium at the Faculty Club of Harvard University, where the professors asked such impertinent questions as: 'Where did you get the sex experiences that are indicated by your writing?' ... I told them, 'From Baruch Spinoza, Immanuel Kant, and George Santayana' ${ }^{25}$

She apparently believed that a woman could be an entirely adequate audience for high cultural forms, but not a producer of them, since her destiny as a woman - to support and inspire male achievement - was incompatible with a serious literary career. This view is informed both by her personal circumstances and by the ideological climate of America between the wars. Regina Barreca connects these two factors: 'Told by her husband and illustrator [Ralph Barton] - and in myriad ways by the culture at large - that women could not write and still be truly feminine, that women's writing was therefore by definition unnatural, even aberrant, Loos ... considered herself monstrous' ${ }^{26}$ Loos's respect for her husband lessened dramatically when she saw he felt threatened by her ability to write material which she herself considered as relatively valueless. Yet she also experienced severe guilt because she felt her success had ruined his life.

Loos's experience is in some respects typical. Elaine Showalter writes that for American women in the 1920s and 1930s, 'Encountering the real tensions between their writing and their personal lives led to disillusionment', and that 'hostility towards female authorship and feminine values in academia and the literary establishment further stigmatized women's writing' ${ }^{27}$ Although many of the admirers and readers of Gentlemen Prefer Blondes were men, ${ }^{28}$ an hostility towards women's writing is evident in the comments on the novel made by certain male intellectuals. William Faulkner wrote to Loos in 1925:

Please accept my envious congratulations on Dorothy - the way you did her through the intelligence of that elegant moron of a cornflower. Only you have played a rotten trick on your admiring public. How many of them, do you think, will ever know that Dorothy really has something ... My God, it's charming ... most of them will be completely unmoved even your rather clumsy gags won't get them - and the others will only find it slight and humorous. The Andersons [Sherwood and Elizabeth] even mentioned Ring Lardner in talking to me about it. But perhaps that was what you were after, and you have builded better than you knew: I am still rather Victorian in my prejudices regarding the intelligence of women, despite Elinor Wylie and Willa Cather and all the balance of them. But I wish I had thought of Dorothy first. ${ }^{29}$ 
At first unwilling to reduce Loos to the level of her mass readership, Faulkner creates a complicity between her as a witty, intellectual writer and himself as a perceptive, discerning reader, understanding the humour which the generality of the 'public' will miss. But this is immediately modified, as he begins to suggest that the author herself may not have recognized the subtlety which he sees in the text ('you have builded better than you knew'). Initially, Faulkner rightly associates Loos with the witty Dorothy, but subsequently he seems to consider her as another Lorelei - clumsy in her jokes and usually funny by accident rather than design.

Evidently, by Faulkner's own admission, a sexist outlook is one reason for his unwillingness to credit Loos's achievement fully. John T. Matthews mentions another factor: 'Faulkner's deprecation of Loos and her novel in the very letter meant to flatter them substantiates the serious modernist's contempt for popularity with the masses'. ${ }^{30}$ The simple fact of Loos's immense popular success probably did count against her in the eyes of highbrows, but it should be remembered that a number of books by serious, 'literary' writers had themselves recently become bestsellers, among them E.M. Forster's A Passage to India (1924); Edith Wharton's The House of Mirth (1905), The Age of Innocence (1920), and A Mother's Recompense (1925); Sinclair Lewis's Main Street (1920), Babbitt (1922) and Arrowsmith (1925); and Willa Cather's The Professor's House (1925). ${ }^{31}$ Besides these, several other American literary novels had achieved both high sales and critical acclaim, notably John Dos Passos's Three Soldiers (1921) and Manhattan Transfer (1925); Theodore Dreiser's An American Tragedy (1925); and F. Scott Fitzgerald's This Side of Paradise (1920). Presumably, therefore, commercial success alone would not necessarily preclude an author from being taken seriously. In Loos's case, high sales did have a damaging impact on her literary status, and I would suggest that this was partly due to the perception of her as mercenary. Writers with an established reputation for serious literature, such as Forster or Wharton, were unlikely to be suspected of purposely attempting to write a bestseller, whereas Loos's thirteen years' experience as a Hollywood screenwriter and film producer inevitably associated her with a materialistic, commodity-based culture. Also, her heroine is the ultimate gold-digger, and the tendency among readers to conflate author and heroine seems to have come into play.

Although the nineteenth-century ideal of the author as anonymous gentlemen or lady amateur was an anachronism by 1925, 'the spectre 
of the hack', as Clive Bloom puts it,$^{32}$ still haunted serious writers. Popular fiction was already perceived as the expression of mass consumer and industrial society, and was therefore condemned by authors who wished to dissociate themselves from the world of commerce. The judgement of Loos as commercial hack underlies Q.D. Leavis's remark, in Fiction and the Reading Public (1932), that Gentlemen Prefer Blondes is a book 'whose slick technique is the product of centuries of journalistic experience and whose effect depends entirely on the existence of a set of stock responses provided by newspaper and film.' ${ }^{33}$ Loos recalls that H.L. Mencken suggested she send her story to a women's magazine, so that they could 'put it in among the ads' ${ }^{34}$ This deliberate association of her fiction with the commercial is intriguing because, as Sarah Churchwell argues, the text itself is 'pervaded by contemporary anxieties about cultural capital, advertisement, imitation, and the middlebrow'. ${ }^{35}$ Such anxieties evidently inform the hostile or ambiguous responses of Mencken, Leavis and, most strikingly, Wyndham Lewis in his chapter on Loos and Gertrude Stein in Time and Western Man (1927). He points to the 'identical' tone and verbal tricks adopted by the two writers and describes them as 'fundamentally alike', yet distinguishes between them as follows: 'Miss Stein ... is a ponderous romantic of the Conrad type; whereas Miss Loos is a lightly ballasted bestseller only, working on the same lines. In perspective the latter will appear as a small mercenary practitioner of the school of Stein'. Lewis goes on to argue that 'Miss Stein has certainly never had any unvirtuous and mercenary intentions of the kind besetting Miss Loos; she has never needed to be a bestseller. ${ }^{36}$ The early publication history of Blondes does not, however, suggest a designedly commercial venture. It was, according to all available sources, written as a short story to amuse H.L. Mencken, and extended and published in instalments at his instigation. A small edition in book form, of 1200 copies, then appeared, but not with one of the middlebrow or popular fiction houses, rather with the prestigious Boni and Liveright, arguably the most important publisher of modernist texts, who had the work of Hemingway, Dreiser, Pound and Eliot on their lists.

Certainly Loos took full advantage of the opportunities for profit and publicity provided by the unexpected success of her story, ${ }^{37}$ but so did Gertrude Stein when her Autobiography of Alice B. Toklas became a bestseller six years later (although Lewis could not have predicted this). Stein embraced the supposedly 'unvirtuous' world of 
Hollywood celebrities to which Anita Loos belonged, noting in Everybody's Autobiography (1937):

We were to go to dinner at Beverly Hills which is the same as Hollywood this I have said we were to meet Dashiell Hammett and Charlie Chaplin and Anita Loos and her husband and Mamoulian who was directing everything and we did. Of course I liked Charlie Chaplin ... we both liked talking but each one had to stop and be polite and let the other one say something. ${ }^{38}$

Stein also immersed herself in consumer culture:

in six weeks I wrote The Autobiography of Alice B. Toklas and it was published and it became a best seller and ... I bought myself a new eight cylinder Ford car and the most expensive coat made to order by Hermes ... I had never made any money before in my life and I was most excited' ${ }^{39}$

She here explicitly characterizes her work as a rapid production, in the same way that Loos describes herself as having dashed off her fictions and scenarios. This doubled gesture evinces both a disarming modesty about the value of their work and a concealed pride in their ability to judge public taste and satisfy it with so little effort.

At the time when Wyndham Lewis wrote his piece, however, Loos had already achieved commercial success while Stein was still appreciated primarily by the avant-garde. On the basis of this distinction between the two authors, Lewis makes assumptions about their respective levels of 'virtue', and extends this into a judgement of their literary value. Lewis's strategy for privileging modernist experimental writing over other forms is a classic example of one of the processes of consecration described by Bourdieu:

The value of works of art in general - the basis of the value of each particular work - and the belief which underlies it, are generated in the incessant, innumerable struggles to establish the value of this or that particular work ... these struggles ... almost always involve recognition of the ultimate values of 'disinterestedness' through the denunciation of the mercenary compromises or calculating manoeuvres of the adversary, so that disavowal of the 'economy' is placed at the very heart of the field, as the principle governing its functioning and transformation. ${ }^{40}$

Lewis takes no note of the fact that Blondes includes sustained critiques of anti-intellectualism, censorship, consumerism and the 
commodification of art. These critiques focus primarily on Lorelei herself. In her autobiography, Loos describes her heroine as 'a symbol of our nation's lowest possible mentality', ${ }^{41}$ and she continually mocks Lorelei's philistinism and her attempts to disguise it:

Well today Mr Spoffard is going to take me all around to all of the museums in Munchen, which are full of kunst that I really ought to look at, but Dorothy ... is ... going ... to the Half Brow house which is the world's largest size of a Beer Hall. So Dorothy said I could be a high brow and get full of kunst, but she is satisfide to be a Half Brow and get full of beer. But Dorothy will never really be full of anything else but unrefinement. ${ }^{42}$

Predictably, Lorelei can't take much 'kunst' and soon deflects $\mathrm{Mr}$ Spoffard into other ways of spending his time. She has no stamina for serious literature either: when one of her admirers presents her with a set of Conrad's novels, she has to get her maid to read them and tell her what they are about. Lorelei combines lowbrow taste with a pretence at culture and refinement, and through her Loos satirizes the emergence of middlebrow taste, which was represented by its detractors as a bourgeois attempt to hijack and commercialize elite culture.

Lorelei's diary records her supposed longing for intellectual improvement, but in fact, her repeatedly expressed wish to improve her mind is simply a strategy to impress rich men, and thus a function of her desire for economic gain. The novel can be read, as T.E. Blom argues, as 'a classic send-up of the American myth in which a nobody from nowhere defeats the old European values of class and education, and wins all that is thought worth winning - money and fame. ${ }^{43}$ Lorelei's definition of what is 'educational' is the reverse of anyone else's - when visiting Paris, she writes:

in only a few blocks we read all the famous historical names, like Coty and Cartier and I knew we were seeing something educational at last and our whole trip was not a failure .... So when we stood at the corner of a place called the Place Vandome, if you turn your back on a monument they have in the middle and look up, you can see none other than Coty's sign. (Blondes, 52)

Lorelei quite literally turns her back on the solid 'monuments' of history, literature and culture in order to admire the depthless icons of consumerism and luxury. Her only use for cultural products is as a means to enhance her social status. For instance, in But Gentlemen 
Marry Brunettes she decides to help her husband, Henry Spoffard, improve his standing among New York intellectuals:

I gave Henry a supscription to the Book of the Month Club that tells you the book you have to read every month to make your individuality stand out. And it really is remarkable because it makes over 50,000 people read the same book every month'. ${ }^{44}$

In this gesture of hostility towards American middlebrow culture, Loos depicts the Book-of-the-Month Club (which was founded in 1926) as an agent of the levelling-down and commodification of culture, since it ensures the commercial success of certain books and standardizes the reading choices of mass audiences. ${ }^{45}$

By marrying Mr Spoffard, Lorelei achieves wealth and social respectability, but can continue to participate in the popular cultural industry. She works as both a film actress and a fiction writer, using her husband's money to finance her projects. Mr Spoffard's respectability is, however, as much of a sham as Lorelei's. 'He always gets his picture in all of the newspapers because he is always senshuring all of the plays that are not good for peoples morals' (Blondes, 76), and he 'cut[s] out all of the pieces out of all of the photoplays that show things that are riskay. So then they put all the riskay pieces together and they run them over and over again' (Blondes, 102). Mr Spoffard has turned his appetite for the culture of distraction to his advantage - policing it becomes his métier and his route to fame. In the climate of censorship which was developing during the interwar years in response to the film industry, many films now considered classics were severely cut, or had new endings appended, particularly if they depicted transgressive women who did not pay for their sins. This replacement of aesthetic values with rather regressive moral considerations is one of Loos's primary satiric targets.

Like the cartoon strips and West End plays decimated by $\mathrm{Mr}$ Spoffard, Lorelei's autobiographical text is a popular cultural product which has to be made respectable. Lorelei is not only the creative impulse behind the story she narrates, she is also its censor: 'I told [Gerry] things that I would not even put in my diary' (Blondes, 11). The unwritten narrative is at times intriguing:

And then we all got together ... and the gentlemen brought their own liquor. So of course the place was a wreck this morning and Lulu and I 
worked like proverbial dogs to get it cleaned up, but Heaven knows how long it will take to get the chandelier fixed (Blondes, 7).

It is not explained how the chandelier was broken. She revises the narrative of her own past until it almost fits the pattern of a Puritan spiritual autobiography:

So I found out that Miss Chapman had been talking against me quite a lot. So it seems that she has been making inquiries about me, and I was really surprised to hear all of the things that Miss Chapman seemed to find out about me ... So then I had to tell Mr Spoffard that I was not always so reformed as I am now ... So I really cried quite a lot. ... So I told Mr Spoffard that when I left Little Rock I thought that all of the gentlemen did not want to do anything but protect we girls and by the time I found out that they did not want to protect us so much, it was to late.... So then I told him how I finaly got reformed by reading all about him in the newspapers. (Blondes, 92-3)

Lorelei also frequently attempts to censure Dorothy's unruly speech:

I overheard her say to Major Falcon that she liked to become intoxicated once in a 'dirty' while. Only she did not say intoxicated, but she really said a slang word that means intoxicated and I am always having to tell her that ... she really should not say 'dirty' (Blondes, 22).

But Lorelei's efforts to suppress Dorothy are disingenuous, since she records all her friend's rebellious pronouncements, thereby preserving the subversive elements of her story under a veneer of respectability. ${ }^{46}$

In But Gentlemen Marry Brunettes, Dorothy becomes more central, as Lorelei undertakes to tell her life story. In this novel, Loos develops her strategy of simultaneously satirizing high and popular culture. Lorelei gives an account of Dorothy's reception at the house of Mrs Breene, mother of a rich young man who wishes to marry Dorothy. Lorelei emphasizes throughout the generosity of Mrs Breene's conduct, not recognizing its patronising and cruel intentions:

Mrs Breene ... made conversation just as if Dorothy were an equal. And first she asked Dorothy her opinion of quite a few rare old first editions of anteek classic books they had in their libery. ... Well, after Mrs Breene saw that Dorothy had become as uncomfitable as she could be in a libery, she invited her into the Art gallery, to show her a new picture ... And Mrs Breene told Dorothy to look it over carefully, and then tell her what she thought of its 'chiarusquero'. Mrs Breene was so sweet to Dorothy that 
she picked out the most titled aristocrats to introduce her to, even if Dorothy did not know what to call them. But instead of taking the opertunity of making friends, Dorothy only let everybody see her misery. (Brunettes, 199, 202)

Dorothy is not, however, the only person at the party who is uncomfortable with highbrow taste: Mrs Breene's other guests, supposedly 'music lovers', talk loudly over a string quartet and only the butler actually enjoys the music. The guests are far more appreciative of Dorothy's impromptu performance of a comic song and a dance routine she learned at the Ziegfeld Follies. Mrs Breene, anxious to distance herself from popular culture, considers the Follies as 'about the same as red ants' (Brunettes, 202), an attitude which reflects the interwar association of uniform, coordinated dance troupes with mechanization and mass consumption. But her high society guests let her down: they are more susceptible to the seductions of lowbrow entertainment than are their servants. The passage is not a rejection of high art in favour of the culture of distraction, but rather a critique of the hypocrisy of upwardly mobile people with pretensions to culture, and a tendency to use that culture to subdue their social inferiors. The episode also demolishes the myth that taste and appreciation of art are confined to the wealthier classes. A similar multiplication of satiric targets occurs in Loos's later novels No Mother To Guide Her and A Mouse is Born, both set in Hollywood. These texts expose the mercenary foundations of movie culture and the ignorance and lack of taste of those who work within it, but also point to the hypocrisy of writers who attempt to profit from Hollywood whilst preserving an attitude of educated disdain. Loos's satire encompasses both the hypocrisy of the high-minded but avaricious intelligentsia slumming in Hollywood in bad faith and the reverse: the tabloid fantasy of soulful and intellectual starlets.

In Brunettes, Lorelei and Dorothy attend a literary party in Jersey, and among the guests are 'Mr H.L. Mencken, Theadore Dreiser, Sherwood Anderson, Sinclare Lewis, Joseph Hergesheimer and Ernest Boyd' (Brunettes, 138). Lorelei's ignorance of serious modern literature is demonstrated by her initial reluctance to attend this event, but she eventually decides to go 'because some of them do write quite well-read novels' (Brunettes, 138). Her preference for widely-read rather than artistically superior authors is emphatically lowbrow. She is disappointed, however: the party does not match her idea of a 'literary salon', since the guests 'did not even mention their literary 
work' (Brunettes, 138). In marked contrast with the modesty of the Jersey authors is the self-promotion of the Algonquin Round Table, the members of which Loos criticizes using the classic satiric method of having her naïve heroine admire them. Lorelei finds the conversation of the Algonquin set to be friendly and generous, but inadvertently reveals it to be pretentious and self-dramatizing:

first one genius said to another, 'What was that screamingly funny remark you made last Tuesday?' So then he told it and they all laughed. And then it was his turn to ask, 'And what was that terribly clever thing you said on Friday?’ (Brunettes, 142).

The ignorance and parochialism of the Algonquin set is also clearly demonstrated. Lorelei reports that Ernest Boyd, who was not a Round Table regular, came to join the party:

So then Mr Boyd ... asked 'What fellow-literatours did you meet on your trip abroad?' I mean Mr Boyd does not know the etiquet of holding a conversation, and he kept asking questions that had very little reply.

But it turned out that one of them did have a letter to a literatour called James Joyce, but he did not bother to present it, because he said, after all, James Joyce did not know who he was, and why bother to meet somebody who knew so little about the 'Algonquin' that he probably would think it meant a tribe of uncivilized Indians. (Brunettes, 142)

Loos's compliment to Joyce here, in combination with her evident respect for the writers attending the Jersey party, distances her from the realm of the popular and affirms the value of serious literature and high culture. In the book as a whole, however, her position cannot be so straightforwardly expressed, and her attitude to high modernism is difficult to characterize.

Various critics have attempted to characterize it. Wyndham Lewis points out numerous similarities between the prose of Stein and Loos, commenting that they both employ narrators who are 'illiterate', 'naïf, and engagingly childish'. ${ }^{47}$ Lewis cites this similarity only to demolish it by distinguishing between Stein as genuinely experimental and Loos as imitative. It is, however, possible to employ quite the opposite tactic, as Susan Hegeman does. She views Loos as an active participant in the modernist project:

The deliberate depthlessness of Loos's prose has some of Stein's cubist fascination with surface. Indeed, Loos's comical use of illiteracies ..., her 
repetition of words, her simple diction, suddenly seem akin to Stein's stylistic experiments, foregrounding the materiality of language' ${ }^{48}$

Barbara Everett similarly positions Loos in relation to the modernist canon, likening the prose style of Gentlemen Prefer Blondes to that of T.S. Eliot's fragments of verse drama, Sweeney Agonistes, first published in The Criterion in 1926 and 1927. The dramatic 'jazz-age or machine-gun-fire style ${ }^{49}$ on which the success of his fragment depends was, she argues, new to Eliot. Certainly, although Eliot's earlier work had been associated with jazz in several influential contemporary reviews, it was not until Sweeney Agonistes that he wrote extensively in an obviously 'jazz age' manner. ${ }^{50}$ Everett suggests that it may have been Gentlemen Prefer Blondes that 'found him a glittering new set of conventions'. She also claims that Lorelei provided the model for Eliot's two chattering, uneducated good-time girls, with 'their capacity to collapse empty cultures' and their 'farcically blank and yet diamond-hard address to life'. Everett locates the significance of Loos's text in its style and formal innovation, precisely the qualities that high modernists primarily valued:

This structure of complex crudities, the 'Lorelei' style, is a pure urbanpastoral medium of the 1920 s, capable of seeming to sum up in its cadences - with a limpidity that hung in the air for decades - the whole difficulty of maintaining innocence at this late point in human history. Thus, sentences like 'Fun is fun but no girl wants to laugh all of the time' (the one which haunted Empson) or the more famous 'Kissing your hand may make you feel very very good but a diamond and safire bracelet lasts forever' manage to absorb into themselves the whole dissolution of Victorian romanticism in the anarchistic unillusioned 1920s. ${ }^{51}$

Brad Buchanan, taking a somewhat different line, describes Gentlemen Prefer Blondes as 'a satire on modernist literary pretensions', commenting that Lorelei 'has been encouraged to write by a "gentleman friend" who, no doubt mindful of recent experiments in stream-of-consciousness story-telling, has informed her that if she "put down all [her] thoughts it would make a book". 52

Perhaps one method of negotiating between these various assessments of Loos's relation to high modernism is to attend to Lorelei's role as author/narrator. In this aspect, Gentlemen Prefer Blondes differs from better-known examples of stream-ofconsciousness writing. The consciousness of Mrs Dalloway or Stein's 
Melanctha is rendered, not by those characters themselves, but by a third-person narrator. In some of Stein's other work, the naïve persona apparently narrates her own story, but is given no name or identity to separate her clearly from Stein herself. Lorelei Lee, by contrast, has a distinct identity as a fictional character, and narrates her own history. Further, Lorelei explicitly constructs herself as an author. She writes her diary to be read: it is a performance of herself, and it is her first step in a projected literary career: 'So here I am writing a book instead of reading one ... It would be strange if I turned out to be an authoress' (Blondes, 3-4). Indeed, Lorelei's role as author is visible not only in her act of narrating, but also in the plots she creates through her manipulation of other characters in her own story and her multiple and creative self-presentation and self-censorship. This means that her book is counterfeit stream-of-consciousness writing, since by definition, a stream of consciousness cannot be ordered and constructed by its own subject. Thus, in a characteristically doubled manoeuvre, Loos uses Lorelei's prose to parody avant-garde experiment and draw attention to its artificiality, whilst directing a simultaneous attack on the bestselling fiction industry by having her heroine succeed in writing a commercially successful book despite her poor literary skills. Since Loos's texts are identical with Lorelei's own, it is only the structural device of irony that turns the satire against the character rather than the author herself.

In later years, Loos deliberately maintained the fiction of Lorelei as the author of Gentlemen Prefer Blondes. She published, for example, a short essay entitled 'Memoirs of a Best-Selling Blonde', purporting to be written by Lorelei, in which she remarks: 'I wrote [a book] years ago called Gentlemen Prefer Blondes, and it sold like the preverbial hotcakes'. ${ }^{53}$ This kind of strategy could be read as distancing character from author by erasing Loos's name and allowing Lorelei's text to stand alone. On the other hand, by ventriloquizing through her heroine, Loos might be seen to be identifying herself more closely with her. In another instance, Effie Huntriss, heroine of A Mouse Is Born, requests some examples of work by other 'other Authoresses who were born Sexy' to help her write her memoir of her screen career, and is told by the bookseller that 'the only items he had in stock was a book of poetry by an Ancient girl called Sapho and a Modern Authoress called Lorelei Lee' (81). Again, Loos could be modestly distancing herself from the 'sexy' book written by Lorelei, or she could be engaging in a form of self-advertisement - inscribing 
her own book in a tradition of women's writing that goes back to Sappho, and asserting its significance on the literary landscape. Here, as so often, Loos's apparently simple - even simplistic - comments prove unexpectedly complex, and her fictions resist being located in any fixed position in relation to contemporary culture.

Anita Loos's novels are precisely about cultural hierarchies. They satirize both the inanity of mass entertainment and the pretentiousness of highbrows, and even take swipes at the newlyconstituted category of the middlebrow. This is one reason why there is no consensus as to whether the novels themselves should be classified as literary or popular fiction. In combination, the responses of Loos's eminent contemporaries demonstrate that the reception and literary status of Gentlemen Prefer Blondes during the interwar years was, to say the least, ambiguous. The contrast between the admiration of Huxley, Joyce, Wharton, Santayana and Empson, and the contempt of Lewis and Leavis indicates this clearly enough, while the equivocal remarks of Faulkner and Mencken contain this ambiguity within themselves, as does Loos's own tendency to celebrate her own intellect whilst deprecating her literary achievements. All these responses are determined not only by the personal taste of the writers involved but also by a complicated set of factors relating to literary value, mass culture, contemporary morality and the status of women writers. There are several ironies in the hostile reactions to Blondes: Loos wrote about censorship and her book was deemed immoral; she wrote about the commodification of culture and her book was dismissed as a mass-market commodity; she wrote about the anxieties over authenticity and imitation in the interwar period, and her text was judged to be itself an imitation. The primary difference between the admiring and the critical readers of Gentlemen Prefer Blondes is that the former consider Loos as an ironic and perceptive commentator on mass culture and the latter see her as an emanation from that culture, and a producer of its commodities. In fact, Loos's novels are selfconsciously both products and critiques of U.S. popular culture. ${ }^{54}$

\section{Notes}

1. Anita Loos, untitled memoir of Aldous Huxley, in Aldous Huxley: 1894-1963: A Memorial Volume, ed. Julian Huxley (London: Chatto \& Windus, 1966), 89-97 at p. 97. 
2. See Anita Loos, Anita Loos Rediscovered: Film Treatments and Fiction, ed. and annotated by Cari Beauchamp and Mary Anita Loos (Berkeley, LA and London: University of California Press, 2003), 206.

3. Susan Hegeman, 'Taking Blondes Seriously', American Literary History 7.3 (1995): 525-54 at p. 547, p. 525. Feminist attitudes to the film differ sharply. Lucie Arbuthnot and Gail Seneca argue that it 'can be read as a feminist text' which 'celebrates women's pleasure in each other' ('Pre-Text and Text in Gentlemen Prefer Blondes', in Issues in Feminist Film Criticism, ed. Patricia Erens [Bloomington, IN.: Indiana University Press, 1990], 112-25 at p. 112, p. 113). Maureen Turim, by contrast, attacks Hawks's transformation of the female body into 'sex object' and 'commodity' ('Gentlemen Consume Blondes', in Issues in Feminist Film Criticism, 101-11 at p. 106).

4. As Elaine Showalter points out: 'A country taking new pride in its cultural heritage after the war saw only weakness and sentimentality in the contribution women had made to our national literature. In the years following the [First World] war, women writers were gradually eliminated from the canon of American literature as it was anthologized, criticized, and taught.' ('Women Writers Between the Wars', in The Columbia Literary History of the United States, ed. Emory Elliott [New York: Columbia University Press, 1988], 822-41 at p. 824.)

5. There are signs that it has begun. The Folio Society reissue publication of Blondes in 1985 initiated its recuperation as a classic of American literature, and the 1990s saw new editions of Loos's work and half a dozen scholarly articles about her. Reference books and survey studies published in the middle decades of the century omitted Loos, but in more recent literary companions and surveys she tends to be mentioned at least briefly.

6. Barbara Everett, 'The New Style of Sweeney Agonistes', Yearbook of English Studies 14 (1984)" 243-63 at p. 255.

7. Malcolm Bradbury, 'Style of Life, Style of Art and the American Novelist in the Nineteen Twenties', in The American Novel and the Nineteen Twenties, ed. Malcolm Bradbury and David Palmer (London: Edward Arnold, 1971), 11-36 at p. 13.

8. Aldous Huxley, letter to Anita Loos, 14 May 1926. Rpt in Loos, memoir of Aldous Huxley, 89.

9. James Joyce, Letters of James Joyce Vol. I, ed. Stuart Gilbert (New York: Viking, 1957), 246.

10. Wharton to Gaillard Lapsley, 11 April 1926, in The Letters of Edith Wharton, ed. R.W.B. Lewis and Nancy Lewis (New York: Scribners, 1958), 491.

11. Wharton to John Hugh Smith, letters dated 14 and 26 January 1926. Edith Wharton Collection (YCAL MSS 42), Yale University Rare Book and Manuscript Library. Series II, Box 26, Folder 807.

12. Quoted in Gary Carey, Anita Loos: A Biography (New York: Alfred A. Knopf, 1988), 108. Blom notes that when Loos wrote to Wharton suggesting she had overpraised the novel, Wharton replied: 'I meant every word I wrote about "Blondes"' (T.E. Blom, 'Anita Loos and Sexual Economics: Gentlemen Prefer Blondes', Canadian Review of American Studies 7.1 [1976]: 39-47 at p. 39). The editors of Wharton's letters quote, in a footnote, a further letter to Hugh Smith, pronouncing Blondes 'the greatest novel since Manon Lescaut' (491).

13. R.W.B. Lewis, Edith Wharton: A Biography (London: Constable, 1975), 468.

14. William Empson, The Complete Poems, ed. John Haffenden (Harmondsworth: Penguin, 2000), 362, 85, 362. 
15. Hegeman, 'Taking Blondes Seriously', 532.

16. Cover blurb from the first British edition, quoted in Clive Bloom, Bestsellers: Popular Fiction Since 1900 (Basingstoke: Palgrave Macmillan, 2002), 91.

17. Review of Gentlemen Prefer Blondes, American Mercury (January 1926), 127.

18. Likewise, in his letters, Mencken - as Richard J. Schrader points out - 'does not overpraise the more cerebral aspects of Loos's brilliant satire'. ('But Gentlemen Marry Brunettes: Anita Loos and H.L. Mencken', Menckeniana: A Quarterly Review 98 (1986): 1-7 at p. 7). The various accounts of Mencken's reactions are somewhat divergent. Cf Matthew J. Bruccoli, 'Interview with Anita Loos', in Conversations With Writers II, ed. Bruccoli et al (Michigan: Gale Research, 1978), 124-40 at p. 129.

19. Anita Loos, A Girl Like I (1966; London: Hamish Hamilton, 1967), 267.

20. Sarah Churchwell, "Lost Among the Ads": Gentlemen Prefer Blondes and the Politics of Imitation', in Middlebrow Moderns: Popular American Women Writers of the 1920s, ed. Lisa Botshon and Meredith Goldsmith (Boston, MA: Northeastern University Press, 2003), 135-64 at p. 154.

21. Anita Loos, 'The Biography of a Book', rpt. in Gentlemen Prefer Blondes: The Illuminating Diary of a Professional Lady and But Gentlemen Marry Brunettes [Harmondsworth: Penguin, 1998], xxxvii-xlii at p. xxxviii.

22. Andreas Huyssen, After the Great Divide: Modernism, Mass Culture, Postmodernism (Basingstoke: Macmillan, 1986), 47. Aspects of Huyssen's argument particularly his account of mass culture as modernism's other - have been challenged by other critics, who demonstrate the close interdependence and mutual borrowings between avant-garde and popular forms in the period. See for example Michael North, Reading 1922: A Return to the Scene of the Modern (New York and Oxford: Oxford University Press, 1999). However, Huyssen's analysis of the gendering of mass culture as feminine remains important to our understanding of cultural production in the early twentieth century.

23. Bloom, Bestsellers, 9; Billie Melman, Women and the Popular Imagination in the 1920s: Flappers and Nymphs (London: Macmillan, 1988), 45.

24. Marjorie Rosen, Popcorn Venus: Women, Movies and the American Dream (New York: Coward, McGann and Geohegan, 1973) 82.

25. Loos, A Girl Like I 181, 61 et passim, 62-63.

26. Regina Barreca, introduction to Gentlemen Prefer Blondes: The Illuminating Diary of a Professional Lady and But Gentlemen Marry Brunettes by Anita Loos (Harmondsworth: Penguin, 1998), vii-xxiv at pp. xxiii-xxiv.

27. Showalter, 'Women Writers ...', 824.

28. Loos recalls that the news-stand sales of Harper's Bazaar tripled during the serialization, and that the magazine gained a new male audience (Loos, 'The Biography of a Book', xli). Livia Z. Wittmann states that in the U.S. Blondes attracted primarily a male audience. ('Erfolgschancen eines Gaukelspiels: Vergleichende Beobachtungen zu Das Kunstseidene Mädchen (Irmgard Keun) und Gentlemen Prefer Blondes (Anita Loos)', Carleton Germanic Papers 11 [1983]: 35-49 at p. 36).

29. William Faulkner, Selected Letters, ed. Joseph Blotner (London: Scolar Press, 1977), 32 .

30. John T. Matthews, 'Gentlemen Defer Blondes: Faulkner, Anita Loos, and Mass Culture', in Faulkner, His Contemporaries, and His Posterity, ed. Waldemar Zacharasiewicz (Tubingen: Francke, 1993), 207-21 at p. 214. 
31. Definitions of bestsellers in terms of sales achievements vary, and some books were bestsellers in the U.K. but not the U.S., or vice versa. Frank Luther Mott lists books believed to have a total sale of 1 percent of the population of continental America for the decade in which they were published. For the 1920s, his table includes (with the exception of P.G. Wodehouse) only writers of formulaic popular fiction, who are now forgotten. He also lists books which nearly made the 1 percent mark, including Blondes as well as The House of Mirth, The Age of Innocence, Main Street and Babbitt. (Golden Multitudes: The Story of Best Sellers in the United States [New York: Macmillan, 1947], appendices, n.p.). Q.D. Leavis, in Fiction and the Reading Public (1932; London: Chatto \& Windus, 1968), selects A Passage to India as her representative highbrow bestseller. Marjorie Rosen lists the ten bestselling novels of 1925 in America, including The Professor's House and A Mother's Recompense (82).

32. Bloom, Bestsellers, 12.

33. Leavis, Fiction and the Reading Public, 218.

34. John Kobal, People Will Talk: Personal Conversations with the Legends of Hollywood (London: Aurum Press, 1986), 89.

35. Churchwell, 'Lost Among the Ads', 135.

36. Wyndham Lewis, Time and Western Man, ed. Paul Edwards (1927; Santa Rosa: Black Sparrow Press, 1993), 56, 57, 59.

37. Loos dramatized Gentlemen Prefer Blondes for the New York stage in 1926, and it toured successfully. She scripted both the 1928 and the 1953 films, as well as the 1955 film Gentlemen Marry Brunettes. With Joseph Fields she wrote the book for a musical version of Blondes in 1949. Commercial spin-offs included a comic strip, dress material and a wallpaper design. (Anita Loos, 'A Musical Is Born', The New York Times [4 December 1949], rpt. in Fate Keeps on Happening, 58-61 at p. 59)

38. Gertrude Stein, Everybody's Autobiography (New York: Random House, 1937), 282-83.

39. Ibid., 40. She even agreed to be photographed alongside a new Ford for an advertising brochure, thereby becoming herself commodified.

40. Pierre Bourdieu, The Field of Cultural Production, ed. Randal Johnson (Cambridge: Polity, 1993) 79.

41. Loos, A Girl Like I, 266.

42. Anita Loos, Gentlemen Prefer Blondes: The Illuminating Diary of a Professional Lady. Published together with But Gentlemen Marry Brunettes (Harmondsworth: Penguin, 1998), 86. All further references are given in parentheses. Language errors in quotations from Loos's fiction are Lorelei's.

43. Blom, 'Anita Loos and Sexual Economics', 40.

44. Anita Loos, But Gentlemen Marry Brunettes. Published together with Gentlemen Prefer Blondes (Harmondsworth: Penguin, 1998) 135. All further references are given in parentheses.

45. On the Book of the Month Club, see Janice Radway, 'The Scandal of the Middlebrow: The Book-of-the-Month Club, Class Fracture, and Cultural Authority', South Atlantic Quarterly 89 (1990): 703-36; Joan Shelley Rubin, The Making of Middlebrow Culture (Chapel Hill: University of North Carolina Press, 1992).

46. Ironically, Loos's male friends tried to censor Gentlemen Prefer Blondes itself. In the first volume of her autobiography, Loos relates that 'Lorelei ... was considered by my 
mentor, Crownie, as such hot stuff that she would smirch my reputation', adding that Crowninshield told Loos's husband John Emerson: 'I wish little Anita had never written that story' (Loos, A Girl Like I, 270).

47. Lewis, Time and Western Man, 55.

48. Hegeman, 'Taking Blondes Seriously', 527.

49. Everett, 'The New Style of Sweeney Agonistes', 252.

50. Clive Bell, Edmund Wilson, John McClure and Burton Rascoe all compared Eliot's poems to jazz in the early 1920s. For details, see North 146. Early drafts of The Waste Land, dating from the very beginning of the 1920s, contain lines in a 'jazz-age' style, which foreshadow Sweeney Agonistes. The final version of The Waste Land contains at least one reference to ragtime.

51. Everett, 'The New Style of Sweeney Agonistes', 254, 250, 253-54, 255.

52. Brad Buchanan, 'Gentlemen Prefer Blondes' in The Cambridge Guide to Women's Writing in English, ed. Lorna Sage (Cambridge: Cambridge University Press, 1999), 268.

53. Anita Loos, 'Memoirs of a Best-Selling Blonde', in Fate Keeps on Happening, 3-6 at p. 3. Published posthumously; date of composition unknown.

54. I am grateful to Professor Rick Rylance and Dr Louise Harrington for detailed comments on this essay, and also to seminar audiences at the Universities of Liverpool, Hertfordshire, Birmingham and Glamorgan, for valuable discussion of my ideas. 